laboratories had to be supplemented with special filters to keep the laboratory free from lead (from lead tetraethyl in anti-knock petrol). The Gladwin tree-ring measurements of traces of helium in rocks, combined with the isotopic ratio of carbon-12 to carbon-13, and radioactive carbon-14, now give ages from twenty thousand years upwards, while the leaduranium ratio can be used to date geological samples at the upper end of the scale to four billion years.

In the Division of Physies the operation of the new synchrotron has steadily improved, and a large and reliable electron beam is always available. The $\mathrm{X}$-rays produced have been used for studying the creation of mesons in hydrogen, a process which proved to be more complex than had been predicted. In the new cosmic-ray laboratory Prof. C. Anderson and his colleagues have found that a charged particle which is heavier than a proton decays into a proton plus a neutral meson. There are also neutral $V$-mesons which decay into two $\pi$-mesons, and $\tau$-mesons which decay into three $\pi$-mesons. Two research units are devoted to problems in jet propulsion, one of which, the Guggenheim Jet Propulsion Centre on the campus of the Institute, is devoted to basic theoretical and experimental studies and to the training of students. The Jet Propulsion Laboratory, five miles from the campus, is financed principally by a contract with the Ordnance Corps of the United States Army; although concerned partly with the development of guided missiles, it also carries out much fundamental research on fuels, thermodynamics, cooling and combustion, electronic guidance and control, and related subjects.

In the Division of Chemistry and Chemical Engineering further progress has been made in the study of various types of hæmoglobin in blood, especially types that cause diseases of the anæmia type. A promising substitute for blood plasma, oxypolygelatine, has been brought to the point of extensive clinical trials. Further light has been shed on the reactions catalysed by the proteolytic enzyme, alpha-chymotrypsin, obtained from bovine pancreas, on the nature of the substance produced by $E$. coli which has the power of causing hæmorrhage in tumours, and of the chemical nature of febrifugine, an antimalarial obtained from a Chinese drug. Studies have been made on coulometric titration, $a$ new method of analysis in which the amount of chemical reaction is measured by determining the amount of electricity used to produce one of the substances participating in the reaction.

A new theory of ferromagnetism has been developed which permits the use of spectroscopic data in predicting the magnetic properties of substances, an electron diffraction technique has been used to determine the molecular structure of volatile boron compounds, ozone, oxygen fluoride and other compounds, and further progress is reported in the application of the phase-shift theory to interpret experimental electron-diffraction data. Additional structural information on amino-acids, simple peptides and other substances related to proteins was obtained during the year, and several synthetic polypeptides proved to possess the configuration of the alpha-helix, a mode of folding the polypeptide chain in which there are 3.6 amino-acid residues per turn of the helix. X-ray photographs indicate that collagen may have a helical structure, with ten units of these amino-acid residues each in three turns or seven turns of the helix, and X-ray photographs of nucleic acids were likewise interpreted to indicate the presence of $a_{0}$ nucleic acid molecule consisting of three helical polynucleotide chains arranged about a common axis. The Chemical Engineering Laboratory continued its work on turbulent flow and on the diffusion of the lighter hydrocarbons in the liquid and gas phases under the conditions encountered in petroleum reservoirs, as well as on the thermodynamic equilibrium of petroleum constituents at the high pressures and temperatures found in deep oil reservoirs.

In the Division of Biology the plaque method of growing animal viruses on monolayer tissue cultures was extended to poliomyelitis virus. Studies on the biosynthesis of proteins included studies on substances that stimulate the formation of red blood cells with consequent increase in total hæmoglobin, the use of cell-free preparations of bacterial cells disrupted by the enzyme lysozyme in the enzymatic incorporation of amino-acids into proteins, lysine metabolism, and the role of polypeptides as intermediates in protein synthesis. Work continued on the electrical disturbances induced in the cortex of animals following various types of electrical stimulation, and the functional activities of the central nervous system of the freshwater crayfish were further mapped. Additional studies were made of the chemical composition and method of action of fertilizin and antifertilizin substances which are important in the fertilization of certain marine animals. Investigations were continued on chromosome aberrations and gene mutations induced in maize by X-rays, gamma-rays and atom-bomb radiations, and the gene concerned with the whiteeye character in Drosophila was studied in an attempt to discover more about the mechanism responsible for this type of position effect. Neurospora enzymes known to be gene-controlled or likely to be useful in genetic studies have been investigated, as well as three closely related genes in the mould Aspergillus concerned with the synthesis of biotin, while many aspects of plant growth, flowering and fruiting have been studied. It has been shown that, under appropriate conditions of light, temperature, air movement, mineral nutrition, etc., tomatoes may yield as much as 160 tons per acre. Factors affecting the growth and production of sugar in the sugar beet were being studied, as well as the growth characteristies and climatic responses of varieties of pea, and the hormonal control of growth, flowering, fruiting and other responses of the higher plants; investigations initiated by Mr. S. Duvdevani, of the Dew Research Station of Israel, as research Fellow of the Institute in 1952, have already shown that many plants can take in water through their leaves and excrete it in liquid form through their roots, thus pointing to the critical importance of a few drops of water for survival under extreme conditions of drought.

\section{FILM-STRIPS OF NORTH AMERICAN NATURAL HISTORY}

$T$

HE use of films as a teaching aid began about a generation ago, and since that time the fortunes of educational film-makers have fluctuated a great deal. While some teachers have been wildly enthusiastic about the value of films in teaching, others have quite genuinely felt that it was an expensive luxury which, while pleasant to use, could never be more than a frill to be used occasionally as 
a change from the essential chalk and talk. With the advent of talking films the enthusiasts felt that the new era of visual aids had arrived. Others, more sober, continued to use the silent film as the more useful adjunct to direct teaching.

Above the noise of controversy remained the still, small voice which eventually compelled most hearing, the matter of finance. Whether sound or silent, films are expensive to produce and, for teachers working on modest budgets, often too expensive to hire. Many teachers wished to make regular use of talking or silent films, but the means were beyond them.

It was into this atmosphere, mainly during the Second World War, that film-strips began to appear. Among their merits are low cost, the light compactness of the projector used in showing them, and the fact that the teacher could vary his teaching to deal with those parts of the film-strip in which his class was interested at any given time. The rise in their use has been rapid. Thousands were made for different purposes in the Armed Forces, while impecunious teachers have been able to buy or borrow them at low cost or even make their own.

It is not unexpected that, as with educational films, among the most popular film-strips have been those dealing with biological subjects. Yet these topies have been mainly 'laboratory' ones, and there are surprisingly fow film-strips dealing with natural history as such. One must be grateful, therefore, to Unicorn Head Visual Aids, Ltd. (Broadway Chambers, 40 Broadway, Westminster, London, S.W.1, price 12s. $6 d$. each) for its enterprise in sponsoring four filmstrips made by the National Film Board of Canada, as follows : the beaver (C.79) ; little brown bat $(C .80)$; North American moose $(C .81)$; and Barren Ground caribou $(C .83)$. The one dealing with the North American moose includes a fine set of lectures illustrating the natural environment in which this mammal lives, its distribution, feeding and breeding habits, its predatory rivals and the use of the moose to man; the strip is supplemented by a valuable script which includes accounts of the moose in legend and folk-lore.

Another strip, on the Barren Ground caribou, although not treated so imaginatively as that on the moose, covers the same range of topies with perhaps more emphasis on its relationship to man; the script describes how to preserve the caribou. Authorities are trying to teach people in the north to feed their dogs on fish, saving the caribou for human use.

The strip on the North American beaver contains a number of frames showing how the animal builds dams and lodges; its interest is heightened by imaginative treatment.

Equally interesting is the strip describing the natural history of the most common bat in Canada, the little brown bat; the accompanying script is well writton with, inter alia, accounts of its eating, drinking and sleeping habits, the method of getting rid of unwelcome bats from domestic properties, and the superstitions about the bat which die so hard.

These four strips would have been popular with the late Sir D'Arcy Thompson, who was constantly urging that biology teachers in schools should not neglect the life-histories of the larger animals of the earth while dwelling on the insides of the smaller. Up-to-date strips of the kind reviewed might be much more popular with children than the re-hashed films of ancient vintage which serve so often as 'entertain. ment' at children's parties to-day.

T. H. HawkINS

\section{REACTIONS OF METHAMO- GLOBIN AND CATALASE WITH PEROXIDES AND HYDROGEN DONORS}

\author{
By PROF. D. KEILIN, F.R.S., and DR. E. F. HARTREE
}

Molteno Institute, University of Cambridge

CTUDY of the reactions of methæmoglobin with different substances was found to be of great help in understanding the mechanism of similar reactions given by other hæmoproteins. We shall examine here the results of some experiments with methæmoglobin and catalase which have a direct bearing upon the much discussed problem of the mechanism of the catalatic decomposition of hydrogen peroxide to molecular oxygen and water.

\section{Reaction of the Methæmoglobin-Peroxide Compound with Different Donors}

Methæmoglobin was obtained from thrice recrystallized horse hæmoglobin which was oxidized either with potassium ferricyanide or with sodium nitrite and exhaustively dialysed against water.

As some of the reactions which will be described here rapidly pass through several stages yielding unstable products, the sequence of reactions has been followed and the unstable intermediates recognized, by changes in the absorption spectra in the visible region observed by means of a low-dispersion microspectroscope.

The reactions of acid methæmoglobin at $p H \quad 6 \cdot 0$ $7 \cdot 3$ with different substances can be summarized as follows.

(1) Acid methæmoglobin, which is brown in colour and shows a characteristic absorption band at $630 \mathrm{~m} \mu$, reacts with hydrogen peroxide forming a red methrmoglobin-peroxide compound ${ }^{1,2}$ with two absorption bands : an asymmetric $\alpha$-band at $589 \mathrm{~m} \mu$ and a stronger $\beta$-band at $545 \mathrm{~m} \mu$. A similar compound is given with ethyl hydroperoxide ${ }^{1}$. The reaction between metmyoglobin and hydrogen peroxide was recently reinvestigated by George and Irvine ${ }^{3,4}$, who found by spectrophotometric titration with ferrocyanide that metmyoglobin-peroxide is only one oxidizing equivalent higher than metmyoglobin itself. They concluded that the compound is not a reversibly formed metmyoglobin-hydrogen peroxide complex but is the product of an irreversible reaction. Moreover, they obtained metmyoglobinperoxide not only with hydrogen peroxide and methyl hydroperoxide but also with other oxjdizing agents such as sodium chlorite, potassium chloriridate and potassium molybdicyanide. Metmyoglobin-peroxide reacts, according to them, as an iron derivative with an effective oxidation number of +4 .

(2) When an excess of hydrogen peroxide is added to methrmoglobin, the peroxide undergoes catalatic decomposition to oxygen and water, while the methæmoglobin becomes reduced to hæmoglobin, which is rapidly oxygenated to oxyhæmoglobin by oxygen generated in the immediate vicinity of the iron atom ${ }^{5}$. This high effective concentration of oxygen explains the very slow formation of carbon monoxide hæmoglobin even when the solution is kept saturated with carbon monoxide. The catalatic decomposition of hydrogen peroxide, as we shall see later, can be described as a peroxidatic oxidation of hydrogen peroxide by methæmoglobin-peroxide, 